\title{
Economic Legitimation in a New Era: Public Attitudes to State Ownership and Market Regulation in China
}

\author{
Sarah Eaton ${ }^{*}$ and Reza Hasmath ${ }^{\dagger}$
}

\begin{abstract}
Autocrats typically seek public support on the basis of economic growth-promotion and redistribution policies, and China is no exception. As important as these factors are for authoritarian resilience, we argue that economic legitimation is a more complex phenomenon than has previously been acknowledged. Beyond improvements in material well-being, citizens form judgements about the state's effectiveness in carrying out a variety of economic roles beyond growth promotion and they also care about the fairness of these market interventions. In this study, we use original survey data collected in late 2015 and early 2016 to evaluate Chinese citizens' perceptions of two economic roles of the state that have been hotly debated in recent years: state ownership and market regulation. We find that while citizens view the ideas of state ownership and interventionist regulation in a generally positive light, suggesting a broad level of agreement in Chinese society about what economic functions the state ought to perform, perceptions of how the state actually carries out these roles are more mixed. Our results show that the urban young are especially inclined to critical evaluations, raising the question of how the Chinese Communist Party's legitimation strategy will fare under conditions of inter-generational value change.
\end{abstract}

Keywords: authoritarianism; state ownership; market regulation; legitimation; China

A growing literature on authoritarian resilience and resurgence emphasizes the importance of strong economic performance in generating popular support for autocrats. ${ }^{1}$ But what precisely constitutes strong economic performance in the

* Humboldt University Berlin. Email: sarah.eaton@hu-berlin.de (corresponding author).

University of Alberta. Email: rhasmath@gmail.com.

1 In post-communist Eurasia, for instance, incumbent autocrats have utilized three general strategies to maintain their popularity: (1) economic populism, (2) anti-Western nationalism, and (3) controlling the media (Dimitrov 2009). Political scientists emphasize the centrality of economic performance in autocratic legitimation (von Soest and Grauvogel 2016; 2017; Dukalskis and Gerschewski 2017). 
minds of citizens living in autocracies? And how do processes of social and economic transformations shape judgements of the state's economic performances? Past research from China and the post-Soviet world suggests that relying on economic growth and expanding household incomes alone is not a viable legitimation strategy for the long run. ${ }^{2}$ This is partly because citizens' implicit benchmarks for evaluating autocrats' economic performance are themselves in flux; public opinion of economic affairs is shaped by belief systems that shift with underlying changes in material circumstances. Processes of ideological and value pluralization that attend economic development can often lead to the emergence of new expectations of the state in its economic functions. ${ }^{3}$ In particular, growing affluence may generate increased demand for relatively meritocratic and impartial "inclusive" economic institutions and a rejection of "extractive" institutions that channel particularistic benefits to regime insiders and supporters. ${ }^{4}$

Our article contributes to the study of authoritarian legitimation in China by examining citizens' views of two critical economic roles of the state beyond growth-promotion - state ownership and market regulation - that shape citizens' overall impressions of the state's economic performance. While scholars have previously analysed public perceptions of the state's economic performances that are most directly tied to individual material well-being, for example growth and redistribution including public goods provision, public attitudes towards these other functions of the Chinese state have yet to be carefully studied. Since both the propriety of state ownership and suitable models of market regulation have stirred passionate debate among policy elites in China, we focus on these policy domains and examine the extent to which expert critiques of the so-called "China model" resonate in wider society. ${ }^{5}$

Based on an original survey conducted in 2015-2016 in six Chinese cities, we find that Chinese citizens have a sophisticated and, on some issues, quite critical view of the state's economic performances in the domains of regulation and ownership. Our results show, first, that there is a high degree of implicit agreement within China about what economic roles the government ought to perform. Most respondents express support for an interventionist state that takes an active role in shaping market outcomes; however, there is a concurrent desire for these interventions to be inclusive, such that market players close to the state, especially state-owned enterprises (SOEs), do not benefit improperly. Further, respondents' evaluations of actual economic performances suggest that the state is not always meeting expectations and this is particularly apparent in public opinion regarding competition policy and pollution control. Finally, statistical analysis shows that young people are, on the whole, both more doubtful about the state's highly interventionist stance in the economy and more likely to see it carrying out its

2 Ma and Wang 2012; Meng and Yang 2012; Junisbai 2014.

3 Inglehart 1977.

4 Acemoglu and Robinson 2012; Hasmath 2015.

5 Wang 2011; Wu, Jinglian 2011; Ferchen 2013; Zhang 2013; Hu 2014; Eaton 2016; Hasmath 2017. 
duties poorly. This last finding raises questions about the efficacy of the state's legitimation efforts vis-à-vis urban youth in the coming years.

\section{Economic Legitimation and Authoritarian Resilience}

An overriding point to emerge from the recent surge in research on authoritarian systems is that autocracies are held together by much more than coercion and repression. Autocrats employ sophisticated means of managing competitive tensions between political elites, and they strive to secure regime stability by generating a degree of popular support for themselves. ${ }^{6}$ The use of economic growth promotion and redistribution to produce "popular" autocracies is especially common. ${ }^{7}$ Indeed, research on legitimation strategies employed by post-Soviet non-democracies finds that among a wide range of legitimating claims including reference to foundational myths, ideology, personalism, international engagement, rule-based procedures and economic performance, rulers are most likely to present themselves as "guardians of citizens' socio-economic well-being.".

The People's Republic of China is arguably the world's best example of such economically "populist authoritarianism." 9 While some might assume that the increasingly harsh repression of a widening circle of perceived opponents of the state - including artists, lawyers, dissidents, activists, journalists, liberal university professors and ethnic minorities in Tibet and Xinjiang - would weaken public support for the Chinese Communist Party (CCP) within China, most available evidence does not support this view. The World Values surveys have consistently shown that Chinese citizens have among the highest rates of confidence in their government in the world. ${ }^{10}$ The most recent data find that fully 85 per cent of Chinese respondents report a "great deal" or "quite a lot" of confidence in government, and this finding of broad public support is supported by a variety of survey-based academic research. ${ }^{11}$ It bears noting, however, that preference falsification likely inflates these figures to some degree. ${ }^{12}$

One commonly finds the claim, in both scholarly and popular discussion, that public backing for China's one-party rule is based, first and foremost, on the state's ability to deliver the goods in economic terms. ${ }^{13}$ Yet, economic growth is an inherently shaky foundation of authoritarian stability. First, the occurrence of economic crisis can be extremely destabilizing if it serves to alter citizens' perceptions of the costs and benefits of authoritarian rule leading to popular uprising

6 de Mesquita and Smith 2011; Svolik 2012; Levitsky and Way 2012; 2013; Boix and Svolik 2013; Schedler 2013; Truex 2014.

7 Dimitrov 2009; von Soest and Grauvogel 2016; 2017; Dukalskis and Gerschewski 2017.

8 von Soest and Grauvogel 2016; 2017.

9 Tang 2016.

10 World Values Survey 2016.

11 Chen 2004; Chen and Dickson 2008; Zhong and Chen 2013; Tang 2016.

12 Tannenberg 2017.

13 Zhao, Dingxin 2009; Zhu 2011; Yang and Zhao 2015. 
and/or engendering divisions within the ruling elite. ${ }^{14}$ In China's market reform period, effective macroeconomic management has kept the nation from falling into deep economic crisis at several critical junctures; however, it has now entered a period of secular slower growth and is struggling to steer around the middle-income trap. An open question regarding this "new normal" (xin changtai 新常态) is whether a prolonged economic slow-down in China, even if it follows a slow and gradual curve, could ultimately threaten the CCP's authoritarian survival.

Further, quite apart from the vagaries of markets, autocrats who base their authoritarian legitimation strategies on economic growth may ultimately wind up as victims of their own success. Processes of social transformation that attend rapid economic development typically lead to shifts in public expectations of the state in the marketplace. Whereas citizens of pre-industrial and industrializing societies tend to be supportive of a highly interventionist role for the state in the economy in line with "survival values" that emphasize deference to state authority, individuals in post-industrial societies are typically more circumspect about state interventions in the economy, in keeping with dominant "self-expression values" emphasizing personal freedom as well as fairness and tolerance in society. ${ }^{15}$ Thus, while robust economic growth may have been a strong anchor of authoritarian legitimation in the early stages of China's reform-era economic development, citizens now accustomed to a higher base of economic well-being feasibly hold more complex expectations of the state. Further, demand for inclusive institutions may conflict with authoritarian survival imperatives since autocrats use economic levers to reward regime loyalists.

\section{Contours of Economic Legitimation in China's New Era}

Judging by debate within Chinese policy circles regarding which economic roles the state should rightfully assume and which activities should instead be left to autonomous market forces, evaluations of the Chinese state's economic performance are increasingly in the eye of the beholder. ${ }^{16}$ In the early days of market reform, a powerful growth consensus meant that economic success was nearly synonymous with GDP growth. Today, China's leaders face a much longer and more challenging list of policy priorities, some of which stand in tension with one another. In addition to maintaining economic growth and steering around the middle-income trap, policymakers simultaneously aim to reverse a

14 Gasiorowski 1995; Ulfelder and Lustik 2007.

15 Inglehart and Welzel 2005.

16 Wu, Jinglian 2011; Hu 2013; Zhang 2013; Eaton 2016. Under Xi Jinping, the space for open debate about economic policy has considerably narrowed and liberal voices have been repressed and increasingly excluded from official media. The state's decision to close the liberal Unirule Institute of Economics in summer 2019 is a case in point. It is reasonable to assume that while liberal voices are increasingly unwelcome in China's public sphere, they continue to play a role in shaping individuals' views of economic affairs, although that effect may diminish over time if the current trend of rigorous censorship of policy debate continues. 
grave environmental crisis (without depressing growth), push China up the value chain, carefully liberalize the capital account, draw down local government debt, reign in industrial overcapacity, and increase social security and healthcare outlays, among other urgent policy challenges. In these vastly more complex circumstances, what are the state's economic performances that count in the eyes of Chinese citizens?

The impression that growth is no longer sufficient to generate a high degree of public consent for one-party rule is supported by Bruce Gilley and Heike Holbig's research on Chinese scholars' discussions of legitimacy. Their analysis of academic articles on the topic of state legitimacy in China from 2002 to 2007 found that "half of all authors mentioned economic growth as a crucial component of a legitimation strategy, while over one third stressed the importance of social equality."17 Zeng Jinghan's follow-up study examining the discourse from 2008 to 2012 found that just 21 per cent of scholars saw economic growth as the key to the state preserving the right to rule. ${ }^{18}$ Scholars "continuously warned about the fleeting nature of performance legitimacy and the necessity of establishing more solid legitimacy foundations, especially rational-legal legitimacy." Zeng concludes that "it is a near consensus that the state should find sources of legitimacy other than economic performance."19 Furthermore, Chinese scholars deemed "changing values" along with "socio-economic inequality" to be the major threats to legitimacy, each of which was cited in almost half of the articles. ${ }^{20}$

If growth is no longer enough to persuade citizens of the CCP's right to rule, which economic functions of the state do citizens care about most? Previous research has also shed light on this question. Based on a nationwide survey, one study finds that citizens place relatively more weight on the state's provision of pure public goods (public security, public safety and legal order) than they do on economic growth in their evaluations of the government's trustworthiness. ${ }^{21}$ Another study suggests that the quality of economic governance is key: citizens' judgements about the fairness of institutional arrangements are of primary importance in shaping their overall impressions of economic performance. ${ }^{22}$

Relatedly, recent literature identifying an ideological spectrum in China would suggest that the particular economic roles the public demands from the state vary somewhat according to individuals' economic beliefs. ${ }^{23}$ The ideological spectrum divides between, on one end, individuals who hold "authoritarian-traditional-nonmarket" values - i.e. those who support authoritarian rule, traditional values and a high degree of state intervention in the economy - and, on the other end, those who embrace

17 Gilley and Holbig 2009, 343.

18 Zeng 2014, 622.

19 Ibid.

20 Ibid., 621.

21 Meng and Yang 2012.

22 Ma and Wang 2012.

23 Wu, Angela Xiao 2013; MacDonald and Hasmath 2018; Pan and Xu 2018. 
"liberal-nontraditional-market" values and who favour political liberalization, oppose traditional socio-cultural norms and support market-oriented policies.

Driven in part by shifting values and ideologies, Chinese citizens' perceptions of the state's economic performance appear to be becoming increasingly varied, nuanced and critical. It would seem that growth alone is no longer sufficient to secure favourable impressions of the state's economic performance. This is especially the case for those who have grown up in a relatively secure economic period. Younger generations increasingly expect the state to extend the benefits of growth to all more deftly and also improve the fairness of market outcomes. In the remainder of the paper, we substantiate this claim through analysis of Chinese citizens' views of two critical duties of the sovereign, state ownership and market regulation.

\section{Methodology}

To study citizens' attitudes to the state's economic performance beyond growth and redistribution, we conducted a pilot online study in the summer of 2014 and followed up with a random digit dialling telephone survey that ran from late 2015 to early 2016. We targeted urban residents (aged 21 and above) located in six cities corresponding to varying levels of socio-economic development and tiers: Beijing and Shanghai (tier-one); Chengdu, Hefei, Hohhot and Wuhan (tier-two). Our sample size was 1,025 respondents, with a sampling scale of 131,291 persons involving 68,162 telephone numbers. ${ }^{24}$ As shown in Table 1, the demographics of our survey sample and those of urban residents from the 2010 census are fairly close.

Our survey employed a seven-point Likert scale to measure the strength of respondents' agreement/disagreement with queries. This analysis focuses on responses to ten question blocks relating to state ownership, competition policy, industrial policy, macroeconomic management and environmental protection.

\section{Perceptions of State Ownership}

In order to provide a detailed picture of public perceptions of state ownership in China, the survey included queries on a range of issues regarding the economic performance of SOEs, as well as the institutional environment encompassing state ownership. The data reveal that Chinese citizens are somewhat favourably disposed to the idea of state ownership, with 58 per cent of respondents expressing some degree of agreement with the statement "sectors related to national security and important to the national economy and people's livelihoods must be controlled by SOEs."

24 The distribution of respondents is as follows: Beijing (16.9\%; N=173), Shanghai $(15.4 \%$; $=158)$, Chengdu (18.6\%; $\mathrm{N}=191)$, Hefei $(16.4 \% ; \mathrm{N}=168)$, Hohhot $(16.4 \% ; \mathrm{N}=168)$ and Wuhan $(16.3 \%$; $\mathrm{N}=167)$. 
Table 1: Sample Demographics

\begin{tabular}{lcclllll}
\hline & $\boldsymbol{N}$ & Age & $\begin{array}{l}\text { Yearly } \\
\text { household } \\
\text { income (yuan) }\end{array}$ & $\begin{array}{l}\text { Education } \\
\text { level }\end{array}$ & $\begin{array}{l}\text { Urban } \\
\text { hukou }\end{array}$ & Male & Married \\
Survey sample & 1,025 & $31-$ & $12,000-60,000$ & Secondary & $57 \%$ & $54 \%$ & $66 \%$ \\
$\begin{array}{l}2010 \text { census } \\
\quad \text { (urban) }\end{array}$ & $N a$ & 34 & $28,843^{*}$ & Secondary & $57 \%$ & $51 \%$ & $60 \%$ \\
$\begin{array}{l}\text { Notes: } \\
* \text { from 2015 China Statistical Yearbook. }\end{array}$ & & & & & & \\
\end{tabular}

There is interesting demographic variation within the data. Statistically significant differences across age categories reveal that the youngest respondents (aged 21-30) in our sample, all of whom belong to the "one-child" generation born after $1980,{ }^{25}$ are significantly less likely to express firm support for state control of key sectors (see Figure 1 and Appendix Table 1). ${ }^{26}$ Support for state ownership increases step-wise in the older age cohorts and is especially pronounced among the oldest participants (aged 51 and over), who are part of the "Cultural Revolution" generation. ${ }^{27}$

While a large proportion of Chinese citizens express support for the idea of state ownership of the "commanding heights" (mingmai hangye 命脉行业) in principle, responses to other questions suggest a degree of latent dissatisfaction with the actual practice of state ownership in certain key sectors. In particular, there appears to be no strong social consensus about what sectors of the economy ought to fall under state ownership, a topic that has stirred considerable controversy in recent years. ${ }^{28}$ Our data provide a detailed look at public opinion on state ownership of a group of SOE-dominated industries including defence, the power grid, petroleum and petrochemicals, telecommunications, coal, civil aviation and shipping. ${ }^{29}$ Defence was the only industry for which a large majority of respondents (68 per cent) agreed that state ownership should predominate. Aggregate support for state ownership of power was 56 per cent, 53 per cent

25 Harmel and Yeh 2015.

26 We employ Ordered Logistic Regression (OLR) to analyse the determinants of support for state ownership and include a range of standard demographic control variables (city of residence, gender, age, highest educational attainment, Communist Party membership, marriage status, average working hours per day, residence status, hukou registration, career, family income and monthly salary). Only age ( $\mathrm{p}$-value of 0.000 ) and residence status ( $\mathrm{p}$-value of 0.022 ) were statistically significant (see Appendix Table 1). Residents who were officially registered in the city in which they were living had more positive views than those registered in another city.

27 Harmel and Yeh 2015.

28 SASAC 2007; World Bank and State Council Development Research Centre 2013.

29 Respondents were not primed in terms of stating that these sectors are actually predominantly state-owned. Nevertheless, many, if not most, respondents would be aware that these are SOE-dominant industries. Most citizens interact with these companies on a regular basis as they provide key utilities and services (mobile communications, air travel, power supply, gasoline). Possible exceptions are defence, coal and shipping industries, since they do not have as direct a linkage to consumers. 
Figure 1: Support for State Ownership by Age

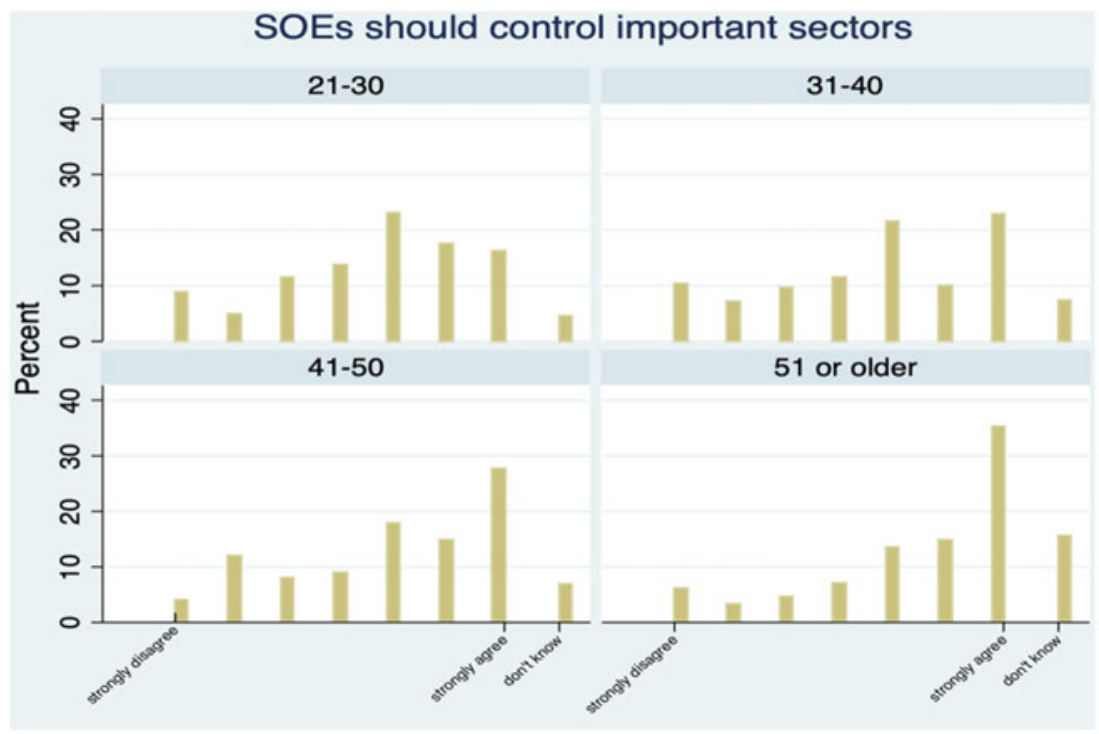

for petroleum and petrochemicals, 52 per cent for coal, 51 per cent for civil aviation and 50 per cent for shipping.

Notably, less than half of respondents agreed that state ownership should predominate in telecommunications, while 36 per cent disagreed (see Figure 2). China's telecommunications industry has been deeply embroiled in the anti-corruption campaign under the leadership of Xi Jinping 习近平 and these doubts about the state's ownership of telecommunications plausibly reflect, in part, the public impact of these scandals. ${ }^{30} \mathrm{~A}$ higher degree of negative affect regarding state ownership of telecommunications may also reflect respondents' misgivings about the state's monitoring and censorship of the internet and mobile communications as well as the popular view that mobile telecommunications costs are unacceptably high owing to the state's monopoly.

Regarding perceptions of the economic performance and competitiveness of SOEs, we find a curious discrepancy. While respondents express reservations about the capabilities of SOE managers, they convey much more faith in SOE

30 The anti-corruption campaign in telecommunications extends much beyond the fall of China Telecom chairman Chang Xiaobing. Between 2009 and 2013, 12 senior officials from China Mobile were removed from office for corruption, including former vice-chairman, Zhang Chunjiang, who was charged with accepting 7.5 million yuan in bribes and handed a suspended death sentence in July 2011. See "China Mobile corruption scandal continues to unfold." The Economic Observer, 26 April 2013, http://www.eeo.com.cn/ens/2013/0426/243169.shtml. A later investigation by the National Auditing Office uncovered evidence of widespread corruption in all three of the major telecommunications service providers (China Mobile, China Unicom and China Telecom). Much of the corruption is related to "power-for-money" deals involving Chinese service providers, a segment of the telecommunications market where foreign companies have played a particularly active role owing to openings in the regulation of this market segment for foreign investment. See Zhao, Hejuan 2012. 


\section{Figure 2: Views of Telecommunications Services}

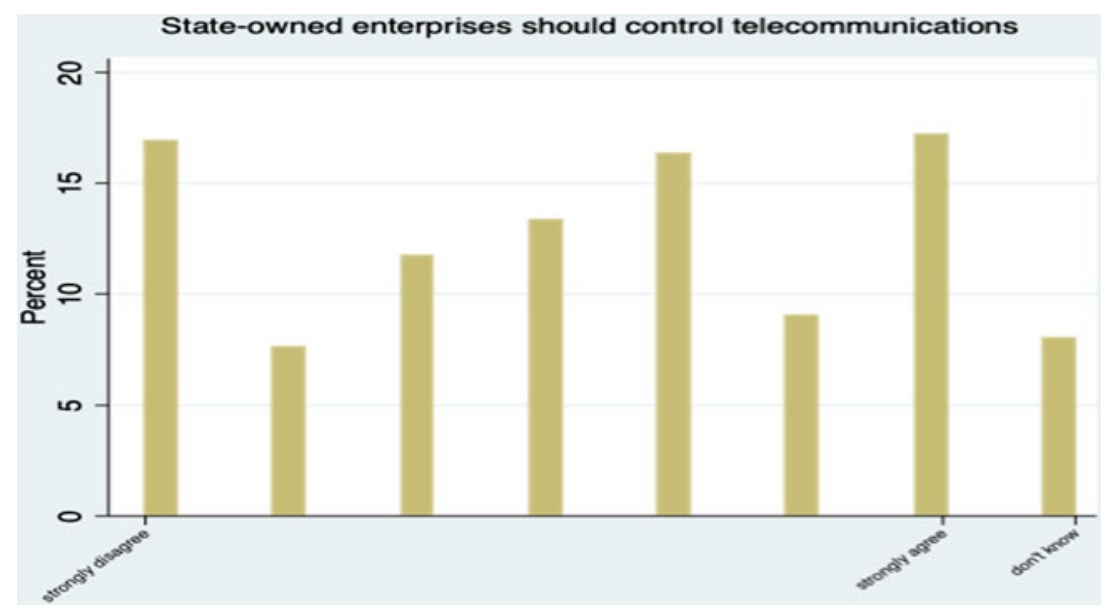

products. Responses to the prompt "state-owned enterprises are well run" show a divided base of opinion with 38 per cent agreeing and 37 per cent disagreeing. Firms of every other ownership type rank above SOEs on this measure (Figure 3). Consistent with our other findings relating to perceptions of state ownership, younger respondents are significantly more likely to view SOE management critically (Appendix Table 2)

Interestingly, the general pattern is reversed when we look at respondents' confidence in the goods and services of firms of different ownership type (Figure 4). Almost two-thirds of respondents (66 per cent) express confidence in SOE products. There are also statistically significant differences across age categories in responses to the query about SOE products with younger respondents as well as men viewing them more critically (Appendix Table 3). How is it that large numbers of respondents perceive SOE management to be poor, but not so their products? The perception of SOEs as prone to corruption (more below) and inherently inefficient owing to the "soft budget constraint" is plausibly shaping respondents' views on this issue. ${ }^{31}$ Respondents may, for example, be relatively satisfied with the electricity supply they receive from the state-run power company and simultaneously regard it to be poorly run because the cost per unit produced is perceived to be too high.

While the benefits of SOE employment have been steadily rolled back in the market reform era, respondents continue to see employment in the state sector in a positive light (Figure 5). We found that 57 per cent of respondents agree that "employees are typically well-treated in SOEs" and only foreign-invested enterprises (FIEs) were evaluated more highly in this category. Respondents' positive impressions of SOE employment may reflect a shift in the preferences 
Figure 3: Perceptions of Enterprise Management by Ownership Type

" $x$ kind of enterprise is well-run"

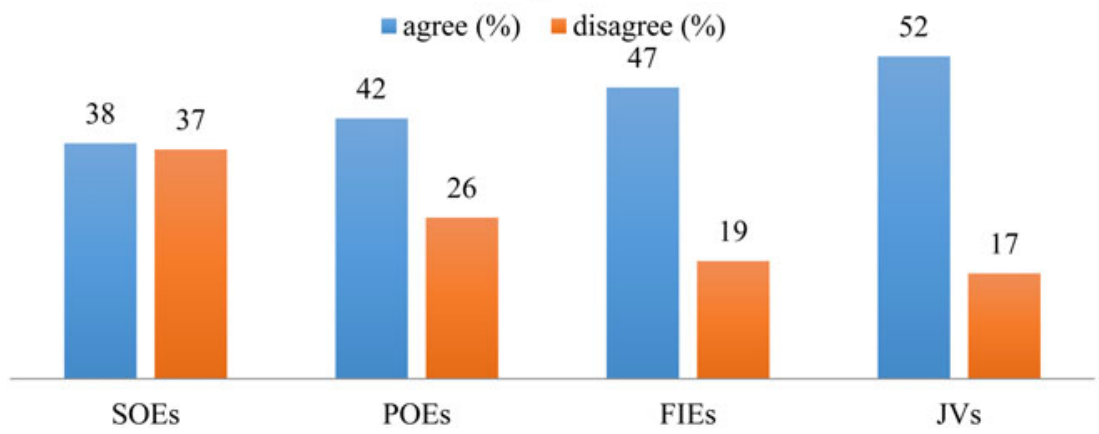

Figure 4: Confidence in Enterprises' Goods and Services by Ownership Type

"I have confidence in the goods and services produced by $x$

kind of enterprise"

66

a agree $(\%)$ = disagree $(\%)$

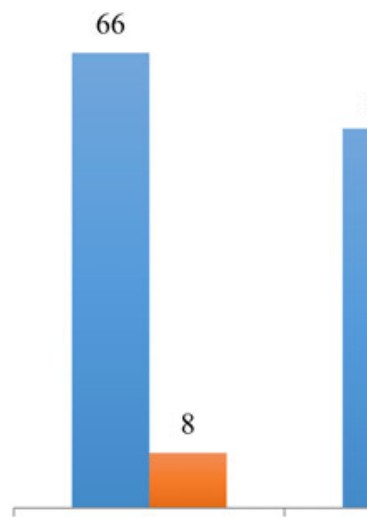

SOEs

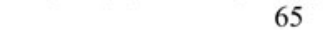

65

62

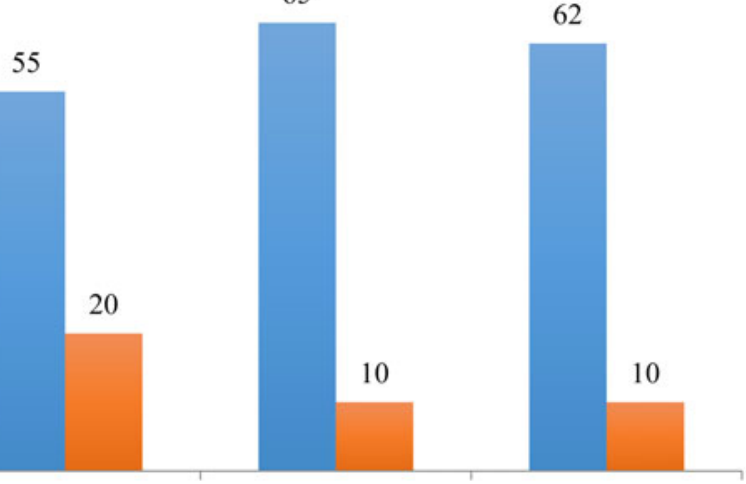

POEs

FIEs

JVs

of university-educated job seekers towards state firms in the years following the global financial crisis and the beginnings of China's economic cooldown. ${ }^{32}$ Analysts speculate that FIEs and private firms' post-crisis struggles made the lure of stable employment in SOEs attractive enough to offset the perceived downsides of SOE employment: low pay and frequently unrewarding work. China's slowing economy likely adds to the appeal of SOE employment relative to employment in firms that are more vulnerable to the ups and downs of markets. Consistent with this view that changing economic circumstances have made

32 "Chinese graduates prefer to work for SOEs and that could be bad for the economy." China Economic Review, 13 August 2014, http://www.chinaeconomicreview.com/chinese-graudates-prefer-working-soesbad-for-economy. 


\title{
Figure 5: Perceptions of Employee Treatment by Firm Ownership Type
}

\author{
"employees are typically well-treated in $x$ kind of \\ enterprise"
}

magree $(\%)$ disagree $(\%)$

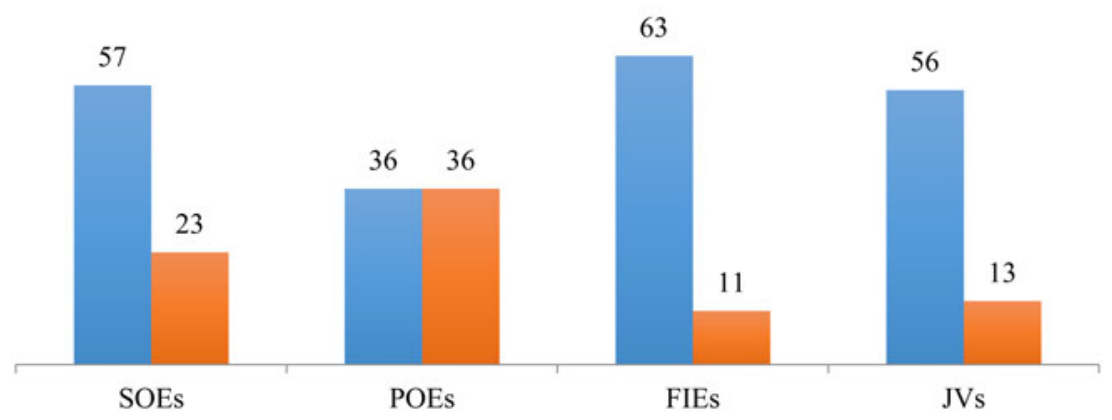

SOE employment appear more positive to young people, there are no statistically significant differences across age categories in responses to the query on SOE employee treatment.

The data reveal a strong linkage between state ownership and corruption in the minds of respondents. More than two-thirds of respondents (69 per cent) report that among firms of different ownership type operating in China, corruption was a major problem in SOEs (Figure 6). On the one hand, this strong association in the minds of respondents between SOEs and corruption is surprising given that the official ideology has long sung the praises of state ownership and emphasized the indispensability of SOEs to the national economy. On the other hand, it is not unexpected when set against the background of a parade of corruption scandals in recent years, many of which have involved SOE leaders. Indeed, the timing of the survey coincided with the busiest phase of the recent anti-corruption campaign, when a new SOE general manager was being placed under investigation virtually every week. ${ }^{33}$

\section{Perceptions of Market Regulation}

The survey produced rich data on many aspects of the state's various interventions in the economy under the banner of market regulation. We collected information exploring respondents' expectations with regard to the state's duties in

33 The following is a partial list of central SOE-linked officials holding ministerial rank or above who have been targeted under the current anti-corruption campaign: Zhou Yongkang (former secretary of China National Petroleum Corporation), Jiang Jiemin (director of SASAC, former chairman of CNPC), Chang Xiaobing (chairman of China Telecom), Li Hualin (deputy general manager of CNPC), Liao Yongyuan (president of CNPC), Si Xianmin (chairman of China Southern Airlines), Song Lin (chairman of China Resources), Sun Zhaoxue (chief exeutive of Chinalco), Wang Tianpu (president of Sinopec), Yao Zhongmin (former vice-governor of China Development Bank), Zhang Yun (president of Agricultural Bank of China) and Cai Xiyou (president of Sinochem Group). 
Figure 6: Perceptions of Corruption by Ownership Type

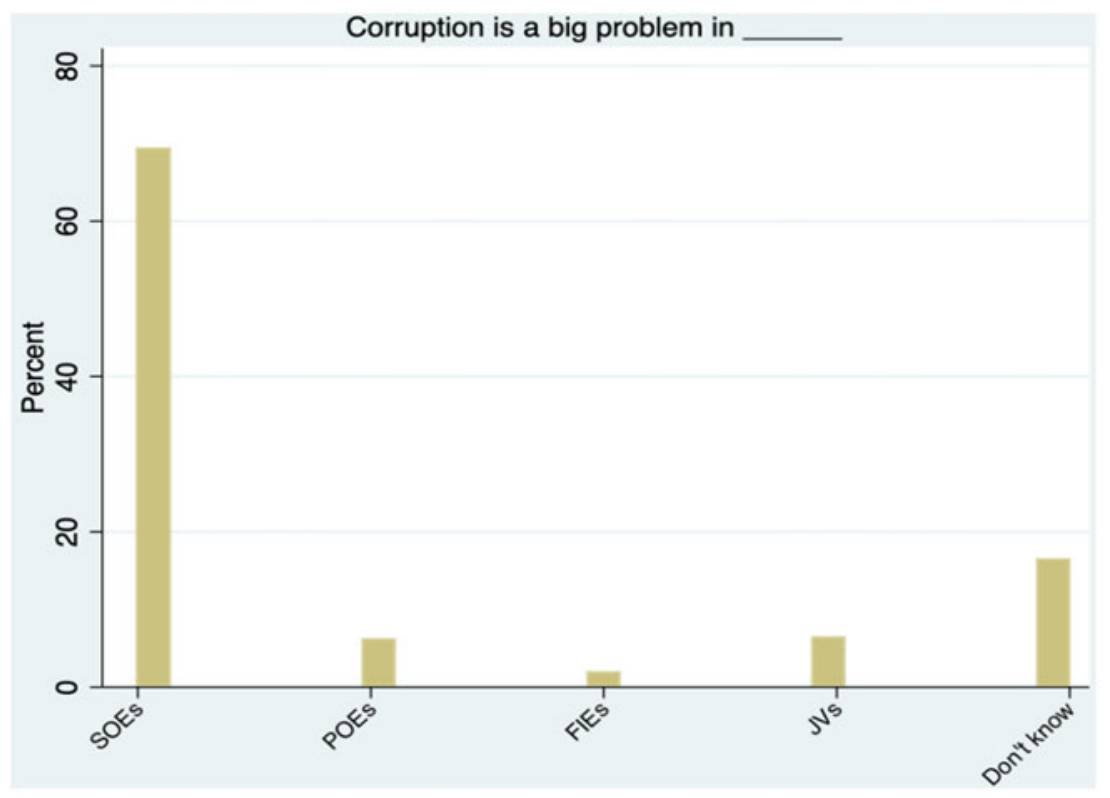

policing and guiding markets and specifically about the degree to which there is public demand for competition policy, industrial policy, Keynesian macroeconomic management, and managing pollution. The data also allow us to compare citizens' expectations of the state against their judgements of actual performance.

\section{Competition policy}

Our data lend insight into Chinese citizens' views of the role of the state in providing a level playing field between firms. Here, we observe a significant gap between citizens' expectations of the state in carrying out this role and their assessments of the state's actual performance. With regard to expectations, a large majority of respondents see the state as having a "responsibility to regulate markets to ensure fair competition between firms" - more than three-quarters of those surveyed (77 per cent) agree with this statement, and within this cohort, half "strongly agree."

However, respondents' expectations are evidently not always being met in the actual practice of market regulation. When prompted to evaluate the state's performance in "ensuring fair competition between state-owned enterprises and private enterprises," more respondents disagreed (43 per cent) that the state is doing a "good job" than agreed (40 per cent). This finding resonates with debate among scholars and policy experts regarding the "advance of the state, retreat of the private sector" (guojin mintui 国进民退) after the global financial crisis and up to the Third Plenum of the 18th Party Congress, when the government was criticized 
by liberal economists for disbursing stimulus funds largely through state-owned firms and sanctioning heavy-handed takeovers of private firms by central SOEs. ${ }^{34}$ Lending further support to the view that younger Chinese tend to hold more pro-market views, there are statistically significant differences between age categories in responses to this question, with younger respondents more likely to evaluate the state's performance critically (Appendix Table 4).

\section{Macroeconomic management}

While many respondents view the state as lacking impartiality in the domain of competition policy, respondents were, on the whole, quite positive about the state's role as the manager of economic crises. Responses to two questions show that most citizens are highly supportive of interventionist measures in times of significant economic stress. Nearly 80 per cent of respondents expressed implicit support for Keynesian crisis management approaches in agreeing that it is the "state's responsibility to stimulate the economy during an economic crisis." A large majority (71 per cent) further believed that "there are key enterprises, whether state-owned or privately owned, that are too big or important to fail, notably during an economic crisis." Moreover, there is strong alignment between the expectations of the state and perceptions of its actual performance as crisis manager. Echoing widespread praise of China's macroeconomic management during the global financial crisis, 71 per cent of respondents agreed that "the state effectively managed China's domestic economy from the recent global economic crisis."

\section{Industrial policy}

The broad support for interventionist measures extends to the expected role of the state in nurturing domestic firms through industrial policy. The vast majority of respondents believe that the state has a duty to support Chinese firms in their efforts to become global players. An overwhelming majority of 87 per cent of respondents agreed that "it is important for the state to develop and encourage a group of globally competitive large enterprises to compete in global markets." This aligns with a finding of strong nationalist sentiment about Chinese firms "going out" into overseas markets (Figure 7). Together, the two results suggest that a vast majority of people expect the government to play the role of "developmental state." 35 Further, they also see China's developmental state as functioning well.

\section{Managing negative externalities}

Another dimension of the state's regulatory role, managing pollution, reveals a pronounced disconnect between respondents' expectations of the state and their 
Figure 7: Nationalist Sentiment Regarding Chinese Firms' Going Out

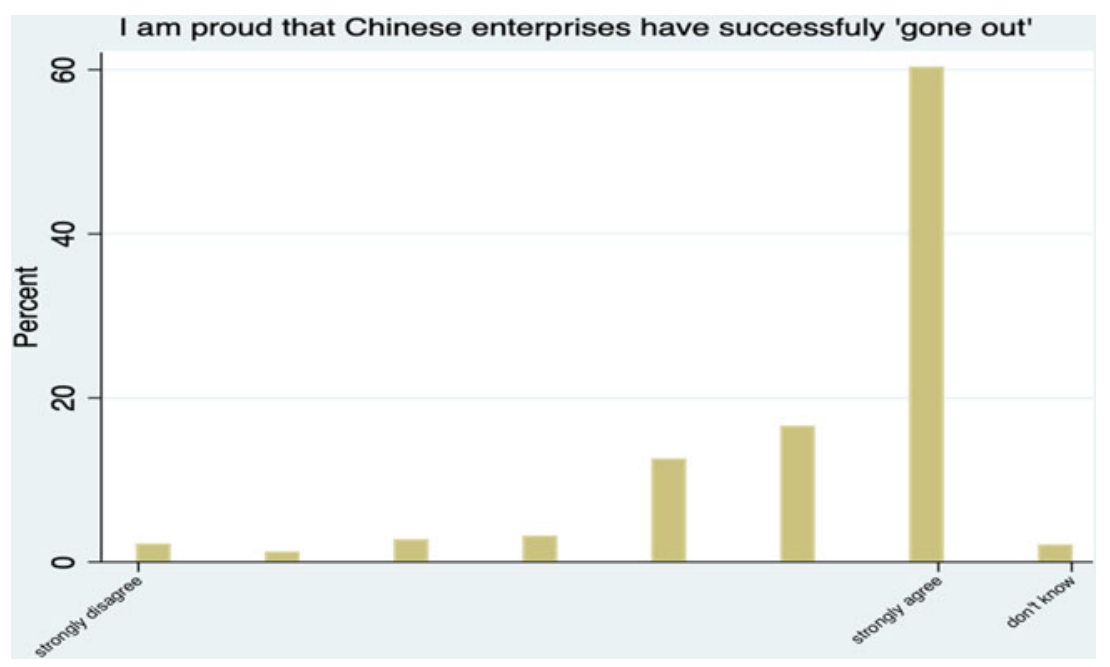

perceptions of actual performance. There appears to be a consensus within China that the state should prioritize environmental protection, even when it involves painful trade-offs. In response to the prompt, "It is the state's responsibility to protect the natural environment, even when doing so could harm economic growth," 86 per cent of the sample agreed, with 57 per cent strongly agreeing. This belief is consistent with the government's growing emphasis on energy savings, emissions reduction and, most notably, clean air since Premier Li Keqiang's 李克强 2014 “declaration of war on pollution” (xiang wuran xuanzhan 向污染宣 战). While it is widely agreed that there have been tangible improvements to environmental governance in China, the remaining gaps between official policy and actual outcomes continue to generate controversy. In analysis of who bears the blame for this "green implementation gap," 36 local governments are most often seen as the culprits since problems of local protectionism of polluting firms and lax enforcement of environmental regulations abound. ${ }^{37}$

When asked about the state's performance in the area of environmental protection, respondents tend to be critical and are especially so of local governments. Consistent with the widely held view that the essential failings of China's environmental system emanate from the bottom of the administrative hierarchy, respondents perceived the central level as performing the tasks of environmental protection best: 60 per cent of respondents agreed with the statement that "the state, at the central level, does a good of protecting the natural environment"; however, younger people along with residents of Beijing and Shanghai are significantly less enthusiastic in their assessments (Appendix Table 5). Relatively

37 Lorentzen, Landry and Yasuda 2014. 


\section{Figure 8: Perceptions of Environmental Protection}

\section{"the state at the $x$ level does a good job of protecting the natural environment"}

= Agree $(\%) \quad$ = Disagree $(\%)$

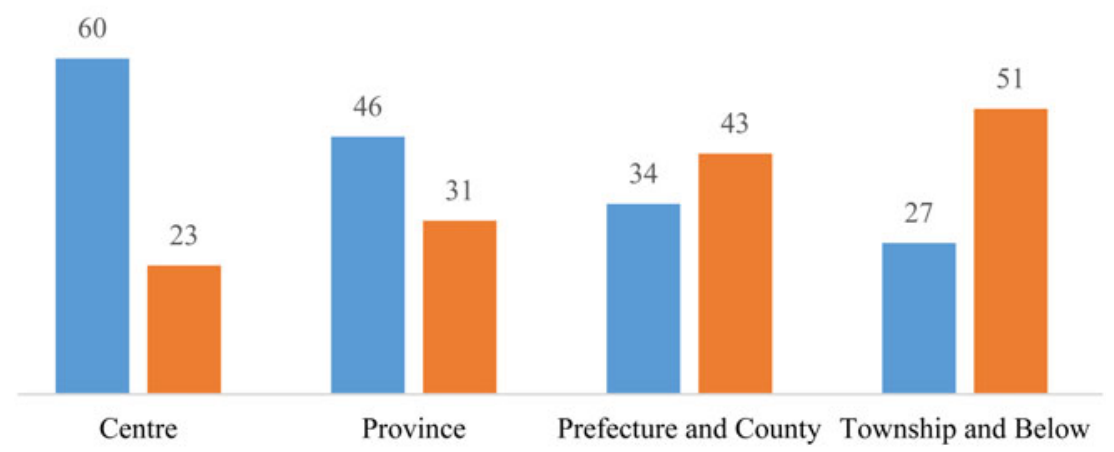

positive appraisals of the centre contrast sharply with respondents' views of local governments. Less than half of respondents (46 per cent) agree that provinces are doing a "good job" of environmental protection. A note of caution is due in interpretations of these data, however, since recent dramatic improvements in air quality in China's urban coastal areas, and above all in the Jing-Jin-Ji 京津 冀 region (Beijing, Tianjin and Hebei province), ${ }^{38}$ may have already generated more positive judgements of the state's environmental performance in targeted urban areas since the time of our survey.

\section{Discussion}

Our results suggest that the Chinese public expect the state not only to perform a wide range of functions in the marketplace beyond growth promotion but also to carry out these duties fairly. While the responses convey a general demand for "inclusive" market institutions, respondents' evaluations of actual performance point to perceptions that state interventions are sometimes "extractive" in their results. This is especially evident in citizens' evaluations of state ownership, which can be differentiated between two things: first, the actual business and products of SOEs, which most respondents see in generally positive terms; and, second, the institutional environment surrounding state ownership, which elicits more sceptical appraisals. While the results convey a strong support for the notion of public ownership overall, younger people in particular are significantly less supportive of SOE monopolies and oligopolies in key sectors of the 
economy. Furthermore, more specific prompts about what exactly the state should own elicit more critical views from all respondents. Survey questions that evoke the non-market privileges that accrue to SOEs in China's state capitalist system also generate sceptical responses. As a whole, the data suggest that not all citizens are convinced of the government's oft-repeated rationales for retaining the state's "controlling force" (kongzhili 控制力) of the economy through large SOEs, particularly central-level firms. ${ }^{39}$

Similarly, our findings on the state's regulatory functions reveal points of agreement between Chinese citizens' expectations and evaluations of the state but also disconnects. In the former category, we find the crisis management and industrial policy functions. A large majority of citizens expect the state to intervene in markets to ward off economic crises and to give domestic firms a leg up in global competition. They also perceive the state to be performing these developmentalist functions well. Yet, significant gaps between expectations and evaluations of actual practice are evident in respondents' opinion of competition policy and environmental protection. In each case, large majorities agree that the state has a responsibility to carry out these duties, but they see much room for improvement in the state's actual performance of these tasks. The data on competition policy echo the findings on state ownership regarding concern about the extractive characteristics of market outcomes when the state serves as both player and referee.

The significance of age in shaping judgements about state ownership and regulatory functions warrants special comment. Our results echo findings in recent studies exploring the impact of age and generational effects on views of market reform and political attitudes in China. Critical attitudes towards one of the most contentious issues in contemporary China, privatization, have been found to increase with age in "nearly a linear, monotonic fashion," with younger people exhibiting significantly stronger pro-market orientations than older cohorts. ${ }^{40} \mathrm{An}$ analysis of political attitudes based on survey data collected in 2008 finds that the "one-child" generation (born in 1980 and later) show a "greater openness to considering deviations from the political/governmental status quo" in addition to a "willingness to criticize and to consider change." ${ }^{41}$ Our results highlighting the strength of pro-market orientations, as well as critical assessments of the practice of state ownership and regulation among the youngest respondents (all of whom belong to the "one child" generation) are consistent with Robert Harmel and

39 Pearson 2005; Eaton 2016.

40 Harmel, Yeh and Liu 2019, 1766.

41 Harmel and Yeh 2015, 232. In contradistinction to generations before them who were socialized in periods of great political tumult and for whom stability is of utmost importance, the one-child generation came of age in a markedly different China. While comparatively politically stable, the marketization period has been marked by rapid social and economic change, growing affluence, the advent of the internet and China's "opening" to the world. These experiences are credited with the one-child generation's higher tolerance for risk, an open attitude to change, as well as higher acceptance of lifestyle and value differences (Harmel and Yeh 2015; Yi, Ribbens and Morgan 2010). 
Yao-Yuan Yeh's conclusions. ${ }^{42}$ Moreover, previous work on the strength of socialist views of economic issues within the Cultural Revolution generation, particularly among former "sent down" youth, ${ }^{43}$ helps to contextualize the sharp upswing in support for state ownership among the oldest respondents, aged 51 and above (Figure 1).

While our analysis sheds new light on citizens' views of key economic roles of the state beyond growth promotion, future studies on this topic could focus on refining this picture. A particular shortcoming of our dataset is the absence of rural respondents and future work should sample opinion from both cities and the countryside. With regard to the possible effects of rural/urban location on perceptions of the state's economic performance, a working hypothesis is that rural respondents are less critical of state performance in the areas of market regulation and ownership. Moreover, given the significant gaps in healthcare and education outcomes between rural and urban China, rural respondents are conceivably more concerned about the quality of public goods provision. Another line of inquiry would incorporate respondents' ideology into the analysis. One would expect respondents subscribing to a "liberal-nontraditional-market" ideology to be relatively more concerned with the fairness of state ownership and market regulation practices but perhaps less attuned to distributional matters. Respondents with an "authoritarian-traditional-nonmarket" ideology are less critical of the state's performance overall, but are more in favour of social policies to be utilized to reduce inequality. Finally, future inquiry could analyse the relative importance that citizens attach to growth promotion, public goods provision, ownership functions and market regulation to discern the state's economic functions that contribute most/least to the state's legitimation.

\section{Conclusion}

While these data reveal a baseline of support for China's economic performances in the ownership and regulation categories overall, there are also indications of dissatisfaction with the "extractive" features of China's state capitalist system. We submit that the critical edge of public opinion revealed in our analysis may be a sign of diminishing political returns to a growth-based authoritarian legitimation strategy. While the extreme hardships and suffering of the Maoist period provided fertile ground for a reformist leadership intent on renewing its right to rule on the basis of "improving the people's livelihood" (gaishan minsheng 改善民生), the great transformation that followed has brought with it roiling social change and the emergence of new values and ideologies. This is

42 Harmel and Yeh 2015. Of course, while our data point to the strength of economically liberal views among China's urban young people, there is also a significant within-generation variation with regard to political attitudes and economic views. For instance, in 2018, a new generation of ardently Marxist students made global headlines when their efforts to defend workers' rights in southern China met with strong repression.

43 Harmel and Yeh 2016. 
especially true of the younger generations whose views are somewhat at odds with China's state-led approach to capitalist development. Increasingly, citizens (notably younger cohorts) expect the state to provide a level playing field whereby the firms that succeed in market competition accomplish this on the basis of their merits and not their connections; what some see is a state that unfairly backs poorly run, corrupt SOEs against a non-state sector superior in management capability, efficiency and dynamism. They believe that a state should stand up for environmental protection and bring an end to growth-at-all-costs; what some see are officials providing cover to industry and turning a blind eye to hazardous levels of water, air and soil pollution. In short, growth alone appears no longer sufficient to sustain positive views of the state's economic performances. If this trend continues to the extent of threatening authoritarian stability, the lessons learned from post-Soviet states is that the state will devote more resources to maintaining their rule and less attention to governance issues. ${ }^{44}$

Herein lies a dilemma for the Communist Party: accommodating demands for inclusive market institutions would entail deep economic reforms of the sort that would effectively dismantle state capitalism. ${ }^{45}$ Yet, doing so could irreparably damage Party patronage networks and possibly even destabilize one-party rule. We surmise that Xi Jinping's administration has decided to forgo deep economic reform - a policy option that appeared very much on the table at the beginning of Xi's tenure ${ }^{46}$ - in favour of shifting its weight to a legitimation strategy that focuses, first, on reducing inequality through poverty alleviation measures and social policy investments; second, on addressing citizens' concerns about environmental crisis and health hazardous pollution; and, third, on cultivating personalist and populist appeals based on the purposive framing of Xi Jinping as a charismatic leader on a par with the "Great Helmsman" Mao Zedong 毛泽东. Our analysis might suggest that this legitimation strategy will have only limited appeal for many younger citizens. As the older generation of dyed-in-the-wool CCP supporters begins to recede from the political equation, the CCP may well find legitimation work vis-à-vis the new generation of urban elites a more arduous task.

46 The end of the Hu Jintao-Wen Jiabao administration (2002-2012) and the early period of Xi Jinping and Li Keqiang's leadership saw a period of intense debate within China about the appropriate direction of economic reform. The definitive document to come out of the Third Plenum of the 18th Party Congress, the "Decision on major issues concerning comprehensively deepening reforms," seemed, in places, to affirm the core of liberal policy prescriptions, especially in its pledge to "allow the market to play the decisive role in resource allocation" and for "government to greatly reduce its allocation of resources." In the years following the Third Plenum, however, one is hard pressed to find examples of a reduced role for government in resource allocation. Developments since the 19th Party Congress in 2018 have only reinforced the view that a state retreat from the economy is unlikely. 


\title{
Acknowledgements
}

The authors are grateful for the valuable feedback received on earlier versions of this article when it was presented at the Association for Asian Studies 2017 Annual Meeting in Toronto; the department of government, Harvard University; the European Political Science Association 2017 Annual Meeting in Milan; the Social Science Research on China Working Group of the German Association for Asian Studies 2016 Conference in Bochum; the Institut de Recherche Stratégique de l'École Militaire; and the University Service Center for China Studies, Chinese University of Hong Kong. We are also thankful for the helpful comments from Genia Kostka and three anonymous reviewers.

\section{Biographical notes}

Sarah EATON is professor of transregional China studies at Humboldt University Berlin. Her research interests lie in Chinese politics and political economy from comparative and transregional perspectives. Before joining Humboldt University Berlin in October 2019, she held professorships at the universities of Göttingen, Oxford and Waterloo.

Reza HASMATH is a professor in political science at the University of Alberta. He has previously held faculty positions in management, sociology and political science at the universities of Toronto, Melbourne and Oxford, and has worked for think-tanks, consultancies, development agencies and NGOs in the USA, Canada, Australia, UK and China. His award-winning research looks at evolving state-society relationships in authoritarian contexts.

\begin{abstract}
摘要：威权政体通常寻求经济发展和再分配政策来获得民众的支持, 中国 也不例外。经济发展对威权政体合法性的支撑比我们想的要复杂得多。除 了物质上的满足, 民众也关注国家在经济领域所扮演的其他角色以及国家 干预的公平性。在 2015 年底以及 2016 年初的一次问卷调查当中, 我们搜 集了关于中国民众对于政府在经济领域最主要也是目前最热门的两个角色 的看法：国家所有制及市场监管。通过这次问卷调查, 我们发现民众对政 府在这两个领域的表现都比较满意。但是，进一步的分析也发现，民众的 满意来源于他们相信政府应该在这两个领域进行干预。但民众对政府实际 的表现却褒贬不一。具体来说, 城市的年轻人更具有批判性, 这也说明中 国共产党获得合法性的策略可能会因为代际更替而受到挑战。
\end{abstract}

关键词: 威权主义; 国家所有制; 市场监管; 合法化; 中国

\section{References}

Acemoglu, Darren, and James Robinson. 2012. Why Nations Fail: The Origins of Power, Prosperity, and Poverty. New York: Crown Business.

Boix, Carles, and Milan W. Svolik. 2013. "The foundations of limited authoritarian government: institutions, commitment, and power-sharing in dictatorships." Journal of Politics 75(2), 300-316. Chen, Jie. 2004. Popular Political Support in Urban China. Washington, DC: Woodrow Wilson Center Press. 
Chen, Jie, and Bruce J. Dickson. 2008. "Allies of the state: democratic support and regime support among China's private entrepreneurs." The China Quarterly 196, 780-804.

de Mesquita, Bruce Bueno, and Alastair Smith. 2011. The Dictator's Handbook. New York: Public Affairs Press.

Dimitrov, Martin. 2009. "Popular autocrats." Journal of Democracy 20(1), 78-81.

Dukalskis, Alexander, and Johannes Gerschewski. 2017. "What autocracies say (and what citizens hear): proposing four mechanisms of autocratic legitimation." Contemporary Politics 23(3), 251-268.

Eaton, Sarah. 2016. The Advance of the State in Contemporary China: State-Market Relations in Contemporary China. Cambridge: Cambridge University Press.

Ferchen, Matt. 2013. "Whose China model is it anyway? The contentious search for consensus." Review of International Political Economy 20(2), 390-420.

Gasiorowski, Mark J. 1995. "Economic crisis and political regime change: an event history analysis." American Political Science Review 89(4), 882-897.

Gilley, Bruce. 2006. "The meaning and measure of state legitimacy: results for 72 countries." European Journal of Political Research 45, 499-525.

Gilley, Bruce, and Heike Holbig. 2009. "The debate on Party legitimacy in China: a mixed quantitative/qualitative analysis." Journal of Contemporary China 59, 339-358.

Greenpeace. 2018. "PM 2.5 in Beijing down 54 per cent, but nationwide air quality improvements slow as coal use increases," 11 January, http://www.greenpeace.org/eastasia/press/releases/climate-energy/ 2018/PM25-in-Beijing-down-54-nationwide-air-quality-improvements-slow-as-coal-use-increases/.

Harmel, Robert, and Yao-Yuan Yeh. 2015. "China's age cohorts: differences in political attitudes and behavior." Social Science Quarterly 96(1), 214-234.

Harmel, Robert, and Yao-Yuan Yeh. 2016. "Attitudinal differences within the Cultural Revolution cohort: effects of the sent-down experience." The China Quarterly 225, 234-252.

Harmel, Robert, Yao-Yuan Yeh and Xinsheng Liu. 2019. "Age versus socialization in understanding attitudes toward economic reforms in China." Social Science Quarterly 100(5), 1755-67.

Hasmath, Reza (ed.). 2015. Inclusive Growth, Development and Welfare Policy: A Critical Assessment. New York: Routledge.

Hasmath, Reza. 2017. "White cat, black cat or good cat? The Beijing Consensus as an alternative philosophy for policy deliberation." China's World 2(1), 12-24.

Heberer, Thomas. 2016. "The Chinese 'developmental state 3.0' and the resilience of authoritarianism." Journal of Chinese Governance 1(4), 611-632.

Hsu, Jennifer Y.J. 2015. "China's development: a new development paradigm?" Third World Quarterly 36(9), 1754-69.

Hu, Angang. 2013. "Guoyou qiye de neihan” (The meaning of state enterprise). Zhongguo zhiliang 12, 38-39.

Hu, Angang. 2014. "Hu Angang: 'liang tiao tui' de Zhongguo bi Meiguo pao de kuai” (China’s "two legs" run faster than America's). Zhongguo ribao, 15 July, http://world.chinadaily.com.cn/2014-07/ 15/content_17782550.htm.

Inglehart, Ronald. 1977. The Silent Revolution: Changing Values and Political Styles among Western Publics. Princeton, NJ: Princeton University Press.

Inglehart, Ronald, and Christian Welzel. 2005. Modernization, Cultural Change, and Democracy: The Human Development Sequence. Cambridge: Cambridge University Press.

Junisbai, Azamat K. 2014. "The determinants of economic system legitimacy in Kazakhstan." Europe-Asia Studies 66(8), 1234-52.

Kornai, Janos. 1986. "The soft budget constraint.” Kyklos 39(1), 3-30.

Kostka, Genia, and Arthur P.J. Mol. 2013. "Implementation and participation in China's local environmental politics: challenges and innovations.” Journal of Environmental Policy and Planning 15(1), 3-16.

Levitsky, Steven, and Lucan A. Way. 2012. "Beyond patronage: violent struggle, ruling party cohesion, and authoritarian durability." Perspectives on Politics 10(4), 869-889.

Levitsky, Steven, and Lucan A. Way. 2013. "The durability of revolutionary regimes." Journal of Democracy 24(3), 5-17. 
Li, He. 2010. "Debating China's economic reform: new leftists vs liberals." Journal of Chinese Political Science 15(1), 1-23.

Lorentzen, Peter, Pierre Landry and John Yasuda. 2014. "Undermining authoritarian innovation: the power of China's industrial giants." Journal of Politics 76(1), 182-194.

Ma, Deyong, and Zhengxu Wang. 2012. "Minzhu, gongzheng haishi jixiao? Zhongguo difang zhengfu hefaxing laiyuan ji qi fenxi" (Democracy, justice or performance? The legitimacy sources of local governments in China). Jingji shehui tizhi bijiao 16(13).

MacDonald, Andrew, and Reza Hasmath. 2018. "Does ideology matter for the citizenry in China? Public attitudes and preferences for economic policies." Paper presented at Midwest Political Science Association Conference, Chicago, 5-8 April 2018.

Meng, Tianguang, and Ming Yang. 2012. "Zhuanxingqi Zhongguo xianji zhengfu de keguan zhili zhengjixiao yu zhengzhi xinren - cong 'jingji zengzhang hefaxing' dao 'gonggong chanpin hefaxing"” (Performance and political trust of China's county-level governments at the transformation stage - from "economic growth legitimacy" to "public goods legitimacy"). Jingji yu shehui tizhi bijiao 4, 122-135.

Pan, Jennifer, and Xu Yiqing. 2018. "China's ideological spectrum.” Journal of Politics 80(1), 254-273.

Pearson, Margaret M. 2005. "The business of governing business in China: institutions and norms of the emerging regulatory state." World Politics 57(2), 296-322.

Pei, Minxin. 2016. China's Crony Capitalism: The Dynamics of Regime Decay. Cambridge, MA: Harvard University Press.

SASAC (State Assets Supervision and Administration Commission). 2007. "Wo guo guoyou jingji buju he jiegou tiaozheng ruogan zhongda wenti de yanjiu" (Research on remaining serious problems in the layout of China's state-owned economy and restructuring). Internal report.

Schedler, Andreas. 2013. The Politics of Uncertainty: Sustaining and Subverting Electoral Authoritarianism. Oxford: Oxford University Press.

Svolik, Milan W. 2012. The Politics of Authoritarian Rule. Cambridge: Cambridge University Press.

Tang, Wenfang. 2016. Populist Authoritarianism: Chinese Political Culture and Regime Sustainability. Oxford: Oxford University Press.

Tannenberg, Marcus. 2017. "Politically sensitive survey items and self-censorship." Afro-Barometer Working Paper No. 176.

Truex, Rory. 2014. "The returns to office in a 'rubber stamp' parliament." American Political Science Review 108(2), 235-251.

Ulfelder, Jay, and Michael Lustik. 2007. "Modeling transitions to and from democracy." Democratization 14(3), 351-87.

von Soest, Christian, and Julia Grauvogel. 2016. "Comparing legitimation strategies in post-Soviet countries." In Martin Brusis, Joachim Arens and Martin Schulze Wessel (eds.), Politics and Legitimacy in Post-Soviet Eurasia. Basingstoke: Palgrave Macmillan, 18-46.

von Soest, Christian, and Julia Grauvogel. 2017. "Identity, procedures and performance: how authoritarian regimes legitimize their rule." Contemporary Politics 23(3), 287-305.

Wang, Shaoguang. 2011. "Tansuo Zhongguoshi shehuizhuyi 3.0: Chongqing jingyan" (Exploring Chinese-style socialism 3.0: the experience of Chongqing), http://www.usc.cuhk.edu.hk/ PaperCollection/Details.aspx?id=7985.

World Bank and State Council Development Research Centre. 2013. China 2030: Building a Modern, Harmonious and Creative Society. Washington, DC: World Bank Press.

World Values Survey. 2016. World Values Survey Wave 6: 2010-2014. Available at: www. worldvaluessurvey.org.

Wu, Angela Xiao. 2013. "Ideological polarization over a China-as-superpower mindset: an exploratory charting of belief systems among Chinese internet users, 2008-2011." International Journal of Communication 8, 2243-72.

$\mathrm{Wu}$, Jinglian. 2011. "Wu Jinglian: xunzu pengzhang wuyi fujia gaige xuyao ding ding ceng sheji” (Wu Jinglian: rent-seeking in the extreme: reform needs a top-level design). Zhongguo gaige, 1 December, 12. 
Yang, Hongxing, and Dingxin Zhao. 2015. "Performance legitimacy, state autonomy and China's economic miracle." Journal of Contemporary China 24(91), 64-82.

Yi, Xiang, Barbara Ribbens and Caryn N. Morgan. 2010. "Generational differences in China: career implications." Career Development International 15(6), 601-620.

Zeng, Jinghan. 2014. "The debate on regime legitimacy in China: bridging the wide gulf between Western and Chinese scholarship." Journal of Contemporary China 23(88), 612-635.

Zhan, Huaxiu. 2013. "Lun 'guojin mintui' de zhengjie yu fazhan fangshi de zhuanbian" (On the crucial reason for "advance of the state, retreat of the private sector" and development style transformation). Jingji yanjiu baokan 9,191, 6-8.

Zhang, Weiying. 2013. "Guoqu shi nian, women de linian da da daotui le" (Over the past decade our thought has greatly moved backwards). IT shidai zhoukan 16, 15.

Zhao, Dingxin. 2009. "The mandate of heaven and performance legitimation in historical and contemporary China." American Behavioral Scientist 53(3), 416-433.

Zhao, Hejuan. 2012. Tianxia you zei (The Invisible Thief). Guangzhou: Nanfang Daily Press.

Zhong, Yang, and Yongguo Chen. 2013. "Regime support in urban China." Asian Survey 53(2), 369-392.

Zhu, Yuchao. 2011. "Performance legitimacy and China's political adaptation strategy." Journal of Chinese Political Science 16(2), 123-140.

\section{Appendix}

\section{Table 1: Perceptions of State Ownership}

\begin{tabular}{|c|c|c|c|}
\hline \multirow[t]{3}{*}{ Ordered logistic regression } & Number of obs & $=$ & 1,000 \\
\hline & LR chi2(12) & $=$ & 66.68 \\
\hline & Prob > chi2 & $=$ & 0.0000 \\
\hline Log likelihood $=-1939.4693$ & Pseudo R2 & $=$ & 0.0169 \\
\hline
\end{tabular}

\begin{tabular}{r|rrrrrr}
\hline stateown & Coef. & \multicolumn{1}{l}{ Std. Err. } & $z$ & $P>|z|$ & [95\% Conf. Interval] \\
\hline city & .0174903 & .0328117 & 0.53 & 0.594 & -.0468194 & .0818001 \\
gen & .066168 & .1129141 & 0.59 & 0.558 & -.1551395 & .2874756 \\
age & .3584964 & .0503527 & 7.12 & 0.000 & .259807 & .4571858 \\
edu & -.0001718 & .0094143 & -0.02 & 0.985 & -.0186234 & .0182799 \\
party & .0024017 & .0065884 & 0.36 & 0.715 & -.0105113 & .0153146 \\
marriage & .0030487 & .0042075 & 0.72 & 0.469 & -.0051979 & .0112952 \\
workhours & .0075108 & .0038501 & 1.95 & 0.051 & -.0000352 & .0150569 \\
res & -.0261856 & .0114024 & -2.30 & 0.022 & -.0485338 & -.0038373 \\
hukou & .0031993 & .0083998 & 0.38 & 0.703 & -.013264 & .0196626 \\
career & .0073291 & .0037948 & 1.93 & 0.053 & -.0001085 & .0147668 \\
faminc & .0250738 & .0517874 & 0.48 & 0.628 & -.0764276 & .1265752 \\
salary & .0028817 & .0021992 & 1.31 & 0.190 & -.0014287 & .007192 \\
\hline / cut1 & -1.329931 & .2990756 & & & -1.916109 & -.7437538 \\
/cut2 & -.7131172 & .2918789 & & & -1.285189 & -.141045 \\
/cut3 & -.1087479 & .289143 & & & -.6754579 & .457962 \\
/cut4 & .445952 & .2887159 & & & -.1199208 & 1.011825 \\
/cut5 & 1.293392 & .2910982 & & & .7228502 & 1.863934 \\
/ cut6 & 1.919 & .2942506 & & & 1.34228 & 2.495721 \\
/ cut7 & 3.655896 & .3132247 & & & 3.041987 & 4.269806 \\
\hline & & & & & & \\
\hline
\end{tabular}


Table 2: Perceptions of SOE Management

\begin{tabular}{llll}
\hline ordered logistic regression & Number of obs & $=1,000$ \\
& LR chi2 $(12)$ & $=$ & 45.48 \\
& Prob $>$ chi2 & $=$ & 0.0000 \\
Log likelihood $=-1993.6885$ & Pseudo R2 & $=0.0113$
\end{tabular}

\begin{tabular}{r|rrrrrr}
\hline S0Ewellrun & Coef. & Std. Err. & $z$ & $P>|z|$ & [95\% Conf. Interval] \\
\hline city & .0316326 & .0325454 & 0.97 & 0.331 & -.0321551 & .0954204 \\
gen & .4115776 & .1128831 & 3.65 & 0.000 & .1903309 & .6328243 \\
ede & .2261939 & .0494472 & 4.57 & 0.000 & .1292792 & .3231086 \\
party & -.0229869 & .0085552 & -2.69 & 0.007 & -.0397547 & -.0062191 \\
marriage & .0048593 & .0065711 & 0.74 & 0.460 & -.0080199 & .0177384 \\
workhours & .004713 & .0042946 & -1.10 & 0.272 & -.0131302 & .0037042 \\
res & -.0001874 & .0114413 & -0.02 & 0.987 & -.0226119 & .0222371 \\
hukou & .0022747 & .0088826 & 0.26 & 0.798 & -.0151348 & .0196842 \\
career & .0066658 & .0034901 & 1.91 & 0.056 & -.0001746 & .0135062 \\
faminc & -.0596323 & .0516897 & -1.15 & 0.249 & -.1609423 & .0416778 \\
salary & -.0013257 & .0022411 & -0.59 & 0.554 & -.0057181 & .0030667 \\
\hline /cut1 & -1.017261 & .2959505 & & & -1.597314 & -.4372092 \\
/cut2 & -.2450769 & .2906989 & & & -.8148362 & .3246824 \\
/cut3 & .5310779 & .289786 & & & -.0368923 & 1.099048 \\
/ cut4 & 1.256103 & .291879 & & & .6840305 & 1.828175 \\
/cut5 & 2.198684 & .297284 & & & 1.616018 & 2.78135 \\
/ cut6 & 2.600716 & .3005774 & & & 2.011595 & 3.189837 \\
/ cut7 & 3.567459 & .3133682 & & & 2.953269 & 4.181649 \\
\hline
\end{tabular}


470 The China Quarterly, 246, June 2021, pp. 447-472

Table 3: Perceptions of SOE Products

\begin{tabular}{lllr}
\hline Ordered logistic regression & Number of obs & $=1,000$ \\
& LR chi2 (11) & $=$ & 30.12 \\
& Prob $>$ chi2 & $=$ & 0.0015 \\
Log likelihood $=-1821.1896$ & Pseudo R2 & $=$ & 0.0082
\end{tabular}

\begin{tabular}{|c|c|c|c|c|c|c|}
\hline SoEprod & Coef. & Std. Err. & $z$ & $P>|z|$ & [95\% Conf. & Interval] \\
\hline city & .0576918 & .0330573 & 1.75 & 0.081 & -.0070993 & .1224829 \\
\hline gen & .2341352 & .1145141 & 2.04 & 0.041 & .0096917 & .4585786 \\
\hline age & .2144484 & .0501773 & 4.27 & 0.000 & .1161027 & .3127941 \\
\hline edu & -.009762 & .0090219 & -1.08 & 0.279 & -.0274446 & .0079206 \\
\hline party & .0047672 & .0059604 & 0.80 & 0.424 & -.0069149 & .0164493 \\
\hline workhours & .002448 & .0039177 & 0.62 & 0.532 & -.0052306 & .0101267 \\
\hline res & -.005195 & .0126417 & -0.41 & 0.681 & -.0299723 & .0195823 \\
\hline hukou & .0050195 & .0104278 & 0.48 & 0.630 & -.0154186 & .0254576 \\
\hline career & -.0025325 & .0035764 & -0.71 & 0.479 & -.0095421 & .0044771 \\
\hline faminc & -.0842349 & .0526956 & -1.60 & 0.110 & -.1875164 & .0190466 \\
\hline salary & -.0003234 & .0022518 & -0.14 & 0.886 & -.0047368 & .00409 \\
\hline /cut 1 & -2.629642 & .3305363 & & & -3.277481 & -1.981803 \\
\hline /cut2 & -1.764538 & .3037289 & & & -2.359835 & -1.16924 \\
\hline /cut 3 & -.8864858 & .2919826 & & & -1.458761 & -.3142106 \\
\hline / cut 4 & -.0902462 & .2895059 & & & -.6576673 & .4771748 \\
\hline /cut5 & 1.275432 & .2935489 & & & .7000869 & 1.850777 \\
\hline /cut6 & 2.14061 & .2982925 & & & 1.555968 & 2.725253 \\
\hline / cut7 & 3.863614 & .326807 & & & 3.223084 & 4.504144 \\
\hline
\end{tabular}


Table 4: Perceptions of Competition Policy

\begin{tabular}{|c|c|c|c|}
\hline \multirow[t]{3}{*}{ Ordered logistic regression } & Number of obs & $=$ & 1,000 \\
\hline & LR $\operatorname{chi2(12)}$ & $=$ & 31.13 \\
\hline & Prob > chi2 & $=$ & 0.0019 \\
\hline Log likelihood $=-1993.6816$ & Pseudo R2 & $=$ & 0.0077 \\
\hline
\end{tabular}

\begin{tabular}{r|rrrrrr}
\hline comppol & Coef. & Std. Err. & $z$ & $P>|z|$ & [95\% Conf. Interval] \\
\hline city & .0476755 & .0328688 & 1.45 & 0.147 & -.0167462 & .1120971 \\
gen & .2183397 & .1131457 & 1.93 & 0.054 & -.0034218 & .4401013 \\
edu & .2182277 & .0496112 & 4.40 & 0.000 & .1209916 & .3154638 \\
party & -.0134612 & .008368 & -1.61 & 0.108 & -.0298621 & .0029398 \\
marriage & -.0043326 & .0069069 & 0.63 & 0.530 & -.0092046 & .0178698 \\
workhours & .0003782 & .0044551 & -0.22 & 0.824 & -.0097205 & .007743 \\
res & -.0157375 & .0119614 & -1.32 & 0.188 & -.0391813 & .0077063 \\
hukou & .0067902 & .0084479 & 0.80 & 0.422 & -.0097674 & .0233477 \\
career & .0000233 & .0035443 & 0.01 & 0.995 & -.0069234 & .00697 \\
faminc & -.0505821 & .0521958 & -0.97 & 0.333 & -.1528839 & .0517197 \\
salary & -.0011206 & .0022187 & -0.51 & 0.613 & -.0054691 & .0032279 \\
\hline /cut1 & -1.044966 & .2917253 & & & -1.616737 & -.4731945 \\
/cut2 & -.4801723 & .2883741 & & & -1.045375 & .0850305 \\
/cut3 & .4850928 & .2877026 & & & -.078794 & 1.04898 \\
/cut4 & 1.036335 & .2889957 & & & .4699135 & 1.602756 \\
/ cut5 & 1.890423 & .2934882 & & & 1.315196 & 2.465649 \\
/ cut6 & 2.281352 & .2966819 & & & 1.699867 & 2.862838 \\
/ cut7 & 3.196865 & .3086416 & & & 2.591939 & 3.801791 \\
\hline
\end{tabular}


472 The China Quarterly, 246, June 2021, pp. 447-472

Table 5: Perceptions of Centre's Environmental Performance

\begin{tabular}{llll}
\hline Ordered logistic regression & Number of obs & $=1,000$ \\
& LR chi2(12) & $=$ & $\mathbf{7 2 . 3 3}$ \\
& Prob $>$ chi2 & $=$ & 0.0000 \\
Log likelihood $=-1876.2608$ & Pseudo R2 & $=$ & 0.0189
\end{tabular}

\begin{tabular}{r|rrrrrr}
\hline centerenv & Coef. & \multicolumn{1}{l}{ Std. Err. } & $z$ & $P>|z|$ & [95\% Conf. Interval] \\
\hline city & .0962618 & .0329817 & 2.92 & 0.004 & .0316189 & .1609047 \\
gen & -.0117418 & .1135204 & -0.10 & 0.918 & -.2342377 & .2107541 \\
age & .3704385 & .0510509 & 7.26 & 0.000 & .2703805 & .4704964 \\
edu & -.0130618 & .0082588 & -1.58 & 0.114 & -.0292488 & .0031252 \\
party & -.0073062 & .0059369 & -1.23 & 0.218 & -.0189422 & .0043299 \\
marriage & -.0039234 & .0046879 & -0.84 & 0.403 & -.0131115 & .0052647 \\
workhours & .0095232 & .0041053 & 2.32 & 0.020 & .0014769 & .0175694 \\
res & -.0017459 & .0114297 & -0.15 & 0.879 & -.0241476 & .0206559 \\
hukou & .0031084 & .0084096 & 0.37 & 0.712 & -.0133741 & .0195909 \\
career & -.0012458 & .003839 & -0.32 & 0.746 & -.00877 & .0062785 \\
faminc & -.0013384 & .0531161 & -0.03 & 0.980 & -.105444 & .1027672 \\
salary & -.0003676 & .0022435 & -0.16 & 0.870 & -.0047647 & .0040296 \\
\hline /cut1 & -1.651631 & .3113771 & & & -2.261919 & -1.041343 \\
/ cut2 & -.9693659 & .2999728 & & & -1.557302 & -.38143 \\
/ cut3 & -.158965 & .2945101 & & & -.7361943 & .4182643 \\
/cut4 & .5587798 & .2942572 & & & -.0179537 & 1.135513 \\
/ cut5 & 1.662705 & .2991687 & & & 1.076345 & 2.249065 \\
/ cut6 & $\mathbf{2 . 5 2 4 3 2 5}$ & .3059587 & & & 1.924657 & 3.123993 \\
/cut7 & 4.743191 & .3536125 & & & 4.050123 & 5.436258 \\
\hline & & & & & &
\end{tabular}

